\section{Accelerated Germination of Pepper Seed by Priming with Salt Solutions and Water}

\author{
Patrick T. Smith ${ }^{1}$ and B. Greg Cobb ${ }^{2}$ \\ Department of Horticultural Sciences, Texas Agricultural Experiment \\ Station, Texas A\&M University, College Station, TX 77843
}

Additional index words. Capsicum annuum, osmoconditioning, priming

\begin{abstract}
Sweet pepper (Capsicum annuum L. CV. Keystone Resistant Giant \#3) seeds were imbibed (primed) in salt solutions to determine a) what concentrations would inhibit radicle emergence and b) the influence this delay in radicle emergence would have on subsequent germination. Seeds were primed for 17 days at $23 \mathrm{C}$ in petri dishes with $\mathrm{KNO}_{3}, \mathrm{KCl}, \mathrm{NaCl}, \mathrm{K}_{2} \mathrm{SO}_{4}, \mathrm{Na}_{2} \mathrm{SO}_{4}, 1 \mathrm{NaCl} 1 \mathrm{CaCl}_{2}(\mathrm{~mol} / \mathrm{mol}), \mathrm{Ca}\left(\mathrm{NO}_{3}\right)_{2}, \mathrm{CaCl}_{2}$, $\mathrm{Na}_{2} \mathrm{HPO}_{4}$, and $\mathrm{K}_{2} \mathrm{HPO}_{4}$ in 10, 25, 50, 100, 200, or $300 \mathrm{~mm}$ of the salts. Germination was not inhibited in the 10- to 100-mm salt range, although most 200- and all $300-\mathrm{mm}$ solutions reduced radicle emergence to $<5.0 \%$. The time to $50 \%$ germination $\left(T_{50}\right)$ of these primed seeds in water significantly $(P<0.01)$ decreased, when compared to unprimed seeds, and a negative correlation $(r=-0.98)$ was observed between this reduction and the osmotic potential of the solutions. Solutions with the highest osmotic potentials most severely reduced $T_{50}$ without reducing the final germination percentage. For seeds primed in $\mathrm{K}_{2} \mathrm{SO}_{4}$ or $\mathrm{Na}_{2} \mathrm{SO}_{4}(200$ and $300 \mathrm{~mm})$ through 18 days, the reduction in $T_{50}$ and duration of priming were negatively correlated $(r=-0.99)$. Seeds soaked in double distilled water and then dried germinated faster than controls, but not as fast as seeds primed in salt solutions. Priming of pepper seeds in this study was dependent on the osmotic potential of the solution, rather than a specific salt, and the duration of treatment.
\end{abstract}

Osmoconditioning (priming) to enhance the rate and the uniformity of germination has been studied extensively (Bradford, 1986; Heydecker and Coolbear, 1977; Heydecker and Gibbins, 1978; Heydecker et al., 1973). Both ionic and nonionic compounds have been effectively used as priming agents (Bradford, 1986).

Two fundamental concepts associated with seed priming are not clearly defined. First, when priming with salts, does the effectiveness of the solution depend on the osmotic potential or the salt species used? Nerson and Govers (1986) suggested that nitrate-containing compounds may function more efficiently than other salts as priming agents, whereas Levitt and Harem (1943) found several salts to be effective for priming. However, in both studies, the osmotic potentials of the salt solutions were not equilibrated. Haigh and Barlow (1987) found that $\mathrm{KNO}_{3}$ was beneficial in decreasing the germination spread for seeds of several species, although the osmotic potential of the solution was a

Received for publication 9 May 1990. Texas Experiment Journal Article no. 23334. Use of a company or product name does not imply approval or recommendation of the product to the exclusion of others which may also be suitable. The cost of publishing this paper was defrayed in part by the payment of page charges. Under postal regulations, this paper therefore must be hereby marked advertisement solely to indicate this fact.

'Present address: USDA, Agricultural Research Service, Northern Region Research, Seed Biosynthesis Research Unit, 1815 N. University, Peoria, IL 61604 .

${ }^{2}$ To whom reprint requests should be addressed. key component to effective priming. When priming with nonionic compounds (PEG), several workers (Atherton and Farooque, 1983; Bodsworth and Bewley, 1981) have reported that the solution's osmotic potential is an essential factor in effective priming.

Second, what influence does the duration of priming have on the overall process? Priming intervals are critical to achieving maximum efficiency of the method (Atherton and Farooque, 1983; Bodsworth and Bewley, 1981; Ely and Heydecker, 1981; Heydecker et al., 1973; Khan et al., 1980/ 81; O'Sullivan and Bouw, 1984). Bodsworth and Bewley (1981) demonstrated a time dependence in priming with PEG. However, a detailed study with many salt solutions over a wide osmotic range has not been presented.

Our research was designed to determine if: 1) effective priming could be achieved with a wide variety of salts without a reduction in the overall germination, 2) the rate of germination after priming depends on a specific salt or the osmotic potential of the priming solution, and 3 ) the duration of the priming treatments was important and whether prolonged exposures to high salt concentrations would reduce the final germination percentage.

Sweet pepper seeds (from the same seed lot) were used for all germination and priming experiments in this study and all were performed with petri dishes in a Lunaire environmental chamber (Percival Manufacturing Co., Boone, Iowa) in darkness at 23C.

Potassium nitrate, $\mathrm{KCl}, \mathrm{NaCl}, \mathrm{K}_{2} \mathrm{SO}_{4}$, $\mathrm{Na}_{2} \mathrm{~S} \mathrm{O}_{4}, 1 \mathrm{NaCl}: 1 \mathrm{CaCl}_{2}(\mathrm{~mol} / \mathrm{mol})$, $\mathrm{Ca}\left(\mathrm{NO}_{3}\right)_{2}, \mathrm{CaCl}_{2}, \mathrm{Na}_{2} \mathrm{HPO}_{4}$, and $\mathrm{K}_{2} \mathrm{HPO}_{4}$ solutions at six concentrations $(10,25,50$, 100,200 , and $300 \mathrm{~mm}$ ) were used to determine which ones could prevent radicle emergence for 17 days. All solutions were initially adjusted to $\mathrm{pH} 7.0$ (with $\mathrm{HCl}$ ), and the osmotic potential of each solution was determined with a Wescor 5100C Vapor Pressure Osmometer at 23C (Wescor, Logan, Utah).

Petri dishes $(60 \times 15 \mathrm{~mm})$ containing two pieces of filter paper (\#2, Micro Filtration Systems, Dublin, Calif.) were used. Fifty seeds were weighed and placed in each petri dish, with three dishes (replicates) per treatment. A sufficient volume $(3.5 \mathrm{ml})$ of each solution was added to partially submerge the seeds. Radicle emergence was checked daily, and germination was defined as radicle emergence of $\geq 2 \mathrm{~mm}$. Salt solutions were changed every 2 days by flooding the petri dish with $10 \mathrm{ml}$ of the respective solution, immediately aspirating away all liquid, and adding back $3.5 \mathrm{ml}$ of priming solution. The priming solutions were changed to maintain a constant osmotic potential of the solutions. Germinated seeds were removed from the petri dishes and discarded,

Seeds were removed after 17 days from solutions where $<5 \%$ of the radicles had emerged. These seeds were rinsed thoroughly with double distilled water $\left(\mathrm{DDH}_{2} \mathrm{O}\right)$ to remove the external salts, placed on paper towels on the laboratory bench, and dried to the original weight under ambient conditions (23C); drying time in all cases was $\approx 24 \mathrm{~h}$. Seed weights were measured before and after priming. The steps noted will be referred to as seed harvesting.

Primed seeds were germinated at $23 \mathrm{C}$ with $\mathrm{DDH}_{2} \mathrm{O}$ in petri dishes. Seed treatments were evaluated by time to $50 \%$ of final germination $\left(\mathrm{T}_{50}\right)$ and the final germination percent-

Table 1. Time to $50 \%$ germination $\left(\mathrm{T}_{50}\right)$ and final germination percentage (FGP) of pepper seeds after priming for 17 days in a variety of salts. Treatments lacking $\mathrm{T}_{50}$ values were those in which seeds germinated during the priming treatment.

\begin{tabular}{|c|c|c|c|c|}
\hline Salt & $\begin{array}{l}\text { Concn } \\
\text { (mM) }\end{array}$ & $\begin{array}{l}\text { Osmotic } \\
\text { potential } \\
(-\mathrm{MPa})\end{array}$ & $\begin{array}{c}\mathrm{T}_{50} \\
\text { (days) }\end{array}$ & $\begin{array}{l}\text { FGP } \\
(\%)\end{array}$ \\
\hline \multirow[t]{2}{*}{$\mathrm{KNO}_{3}$} & 200 & 0.83 & $\cdots$ & 007 \\
\hline & 300 & 1.25 & 0.72 & 88.7 \\
\hline \multirow[t]{2}{*}{$\mathrm{KCl}$} & 200 & 0.89 & $\cdots$ & $\ldots$ \\
\hline & 300 & 1.34 & 1.41 & 88.0 \\
\hline \multirow[t]{2}{*}{$\mathrm{NaCl}$} & 200 & 0.90 & $\cdots$ & $\cdots$ \\
\hline & 300 & 1.35 & 1.89 & 88. \\
\hline \multirow[t]{2}{*}{$\mathrm{K}_{2} \mathrm{SO}_{4}$} & 200 & 1.08 & 0.75 & 95 \\
\hline & 300 & 1.58 & 2.55 & 95.3 \\
\hline \multirow[t]{2}{*}{$\mathrm{NaCl}: \mathrm{CaCl}_{2}$} & 200 & 1.10 & -- & -- \\
\hline & 300 & 1.66 & 2.46 & 88. \\
\hline \multirow[t]{2}{*}{$\mathrm{Na}_{2} \mathrm{SO}_{4}$} & 200 & 1.13 & 1.01 & 92 \\
\hline & 300 & 1.61 & 2.00 & 93. \\
\hline \multirow[t]{2}{*}{$\mathrm{Ca}\left(\mathrm{NO}_{3}\right)_{2}$} & 200 & 1.22 & 1.40 & 89. \\
\hline & 300 & 1.80 & 3.34 & 90. \\
\hline \multirow[t]{2}{*}{$\mathrm{CaCl}_{2}$} & 200 & 1.24 & 1.88 & 96. \\
\hline & 300 & 1.94 & 3.93 & 90. \\
\hline \multirow[t]{2}{*}{$\mathrm{Na}_{2} \mathrm{HPO}_{4}$} & 200 & 1.40 & 2.26 & 78.0 \\
\hline & 300 & 2.02 & 4.27 & 82 \\
\hline \multirow[t]{2}{*}{$\mathrm{K}_{2} \mathrm{HPO}_{4}$} & 200 & 1.43 & 1.78 & 86. \\
\hline & 300 & 2.09 & 4.40 & 90 \\
\hline Control & & & 6.47 & 95.3 \\
\hline \multirow[t]{2}{*}{$\mathrm{LSD}_{0.01}$} & 200 & & 0.31 & 10.5 \\
\hline & 300 & & 0.57 & 7 \\
\hline
\end{tabular}


age (FGP). $\mathrm{T}_{50}$ (Orchard, 1977) was used as the index of the rate of germination. Any decrease in the FGP was attributed to toxic effects of high salt concentrations on the seeds for prolonged (17 days) periods. Germination was monitored for 18 days, although more than $90 \%$ had occurred within the first 7 days. Germination data were analyzed by analysis of variance, and the means were separated by LSD when the F test was significant $(P<0.01)$. For all experiments, untreated seeds germinated in $\mathrm{DDH}_{2} \mathrm{O}$ served as controls.

The effect of the priming duration was tested by priming the seeds with 200 or 300 $\mathrm{mm} \mathrm{Na}_{2} \mathrm{SO}_{4}$ and $\mathrm{K}_{2} \mathrm{SO}_{4}$ for 18 days. Based on the initial studies, these salts inhibited germination during priming and imparted the greatest reduction in $\mathrm{T}_{5_{0}}$ at both concentrations. Seed were harvested at 3-day intervals and then germinated in petri dishes with $\mathrm{DDH}_{2} \mathrm{O}$. Germination was recorded daily for 18 days. Germination data were analyzed as noted above.

In a third experiment, pepper seeds were imbibed in petri dishes with water to determine if water priming would be as effective as priming with salts. Seeds were collected daily through 5 days, dried, and germinated in petri dishes. Germination was recorded daily for 18 days. More than $5 \%$ of the seed population had germinated after the 5 th day and the experiment was terminated.

Seed germination was not delayed in the 10 - to $100-\mathrm{mm}$ solutions (data not shown). In the 200-mm solutions of $\mathrm{KNO}_{3}, \mathrm{KCl}$, $\mathrm{NaCl}$, and $\mathrm{NaCl}: \mathrm{CaCl}_{2}$, germination proceeded at a reduced rate, although the FGP at 17 days was significantly $(P<0.01)$ decreased $(24 \%, 22 \%, 53 \%$, and $17 \%$, respectively) when compared to seeds germinated in water. Seeds from these four treatments were discarded and not used in further trials. Radicle emergence in the six remaining 200$\mathrm{mm}$ and all $300-\mathrm{mm}$ solutions was $<5 \%$ of the total seed population for the 17-day trial. After harvest, primed seeds were germinated in water, and a significant $(P<0.01)$ decrease in $T_{50}$ was observed for all of the treatments compared to the controls (Table 1). Seeds exposed to 200 or $300 \mathrm{~mm} \mathrm{Na}_{2} \mathrm{HPO}_{4}$ were the only samples where the FGP was significantly" decreased (Table 1). A negative correlation $(r=-0.98, P<0.01)$ was observed between the reduction of $\mathrm{T}_{50}$ and the osmotic potential of the priming solution (Fig. 1).

Seeds primed in $\mathrm{Na}_{2} \mathrm{SO}_{4}$, regardless of treatment duration, demonstrated a significant $(P<0.01)$ decrease in $\mathrm{T}_{5_{0}}$ compared to the control (Fig. 2). Similar germination trends and reductions in $\mathrm{T}_{50}$ were observed when priming with $\mathrm{K}_{2} \mathrm{SO}_{4}$ (data not shown). The reduction in $\mathrm{T}_{5_{0}}$ was strongly correlated with the duration of priming through 12 days $(r$ $=-0.99$ and -0.99 for 200 and $300 \mathrm{~mm}$ $\mathrm{Na}_{2} \mathrm{SO}_{4}$ and $r=-0.99$ and -0.99 for 200 and $300 \mathrm{mM} \mathrm{K}_{2} \mathrm{SO}_{4}$, respectively; $P<0.01$ ) (Fig. 2). Priming for longer than 12 days in the 200-mm solutions did not decrease $\mathrm{T}_{50}$ further (Fig. 2). Priming for 15 and 18 days in the $300-\mathrm{mm}$ solutions partially reversed the influences of priming, as reflected in a significant increase in $\mathrm{T}_{50}$ as compared to 12 days of priming (Fig. 2).

Germination rates were significantly enhanced $(P<0.01)$ when seeds were imbibed in water, harvested, and germinated (Fig. 3). These values were similar to the short-term (3 and 6 days) priming treatments with

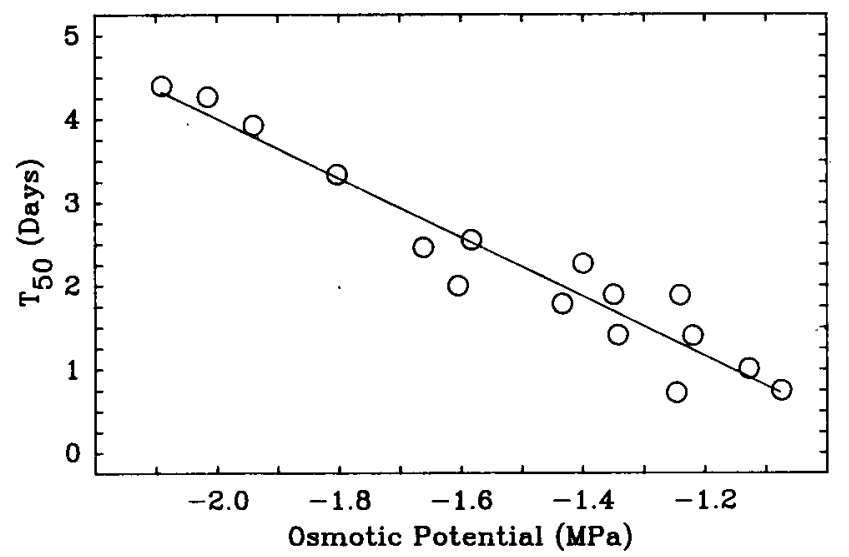

Fig. 1. Regression of the time to $50 \%$ germination $\left(\mathrm{T}_{50}\right)$ on the osmotic potential of the priming solutions for Capsicum annuum seeds primed for 17 days in one of 10 salts at 200 and $300 \mathrm{mM} . r$ $=-0.98 ; \mathrm{y}=-3.56 \mathrm{x}-3.11$.

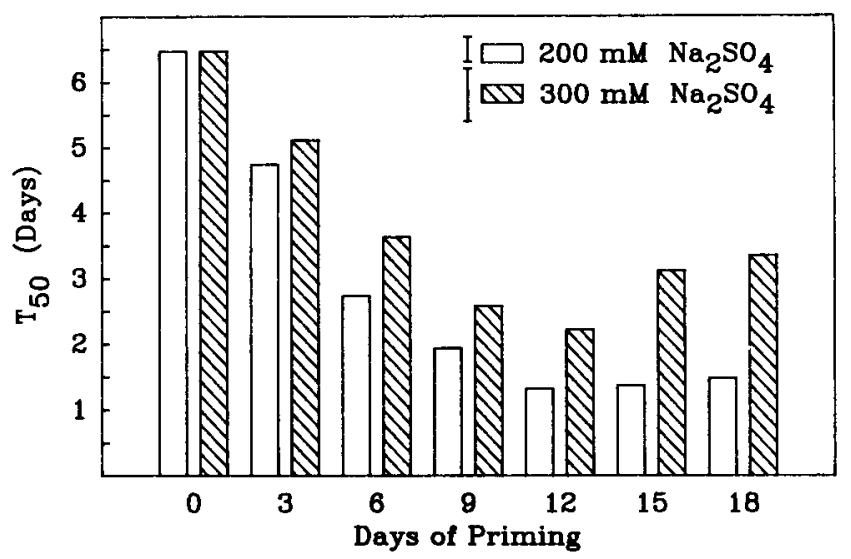

Fig. 2. Time to $50 \%$ germination $\left(\mathrm{T}_{50}\right.$ ) of Capsicum annuum seeds after priming with 200 (open bar) and 300 (hatched bar) $\mathrm{mM} \mathrm{Na}_{2} \mathrm{SO}_{4}$ through 18 days. LSD $(P=0.01)$ values for each treatment are indicated by vertical lines. Similar trends were observed for seed primed with $\mathrm{K}_{2} \mathrm{SO}_{4}$.

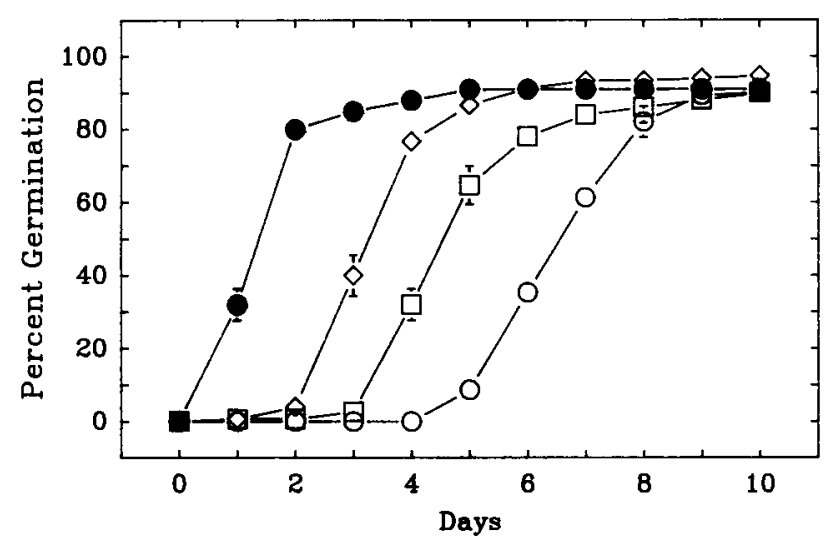

Fig. 3. Germination of Capsicum annuum seeds after imbibing in double distilled water for $0(0), 2$ $(\square)$, or $4(\diamond)$ days. Priming for $12(\bullet)$ days in $200 \mathrm{mM} \mathrm{Na}_{2} \mathrm{SO}_{4}$ is shown to contrast the most effective salt priming treatment with the water imbibition. Although monitored for 18 days, the germination percentages did not change significantly after 10 days for treatments and control (data not shown). Error bars of some points are smaller than the symbol size. 
Yaklich and Orzolek, 1977). Additionally, we found that an essential feature of effective priming for pepper seeds is the osmotic potential of the priming solution. This result strongly supports those of Haigh and Barlow (1987) for priming other species in $\mathrm{KNO}_{3}$, $\mathrm{K}_{2} \mathrm{HPO}_{4}, \mathrm{~K}_{3} \mathrm{PO}_{4}, \mathrm{~K}_{2} \mathrm{HPO}_{4}+\mathrm{KNO}_{3}$, and $\mathrm{K}_{3} \mathrm{PO}_{4}+\mathrm{KNO}_{3}$ from -0.5 to $-1.75 \mathrm{MPa}$. Further, Bodsworth and Bewley (1981) reported that the osmotic potential of the priming solution (PEG) was crucial when priming several different types of seeds. We also showed that priming solutions with the highest osmotic potentials (that prevented germination) resulted in the greatest reduction in $\mathrm{T}_{50}$ (Fig. 1). Similar trends have been observed by Atherton and Farooque (1983) and Haigh and Barlow (1987). While the basis for this trend is unknown, greater metabolic activity may occur in seeds primed at higher water potentials. Bradford (1986) has shown that the degree of seed hydration is correlated with the osmotic potential of the priming solution. Therefore, seeds incubated in solutions with relatively high water potentials have higher moisture contents and potentially greater metabolic activity. Hegarty (1977) has shown that oxygen use is highest in seeds in solutions with the highest osmotic potential. Sundstrom and Edwards (1989) demonstrated high respiratory rates in the initial hours of priming.

The time-course experiments show that the duration of priming is important (Fig. 2), which is supported by previous reports on priming (Bodsworth and Bewley, 1981; Heydecker et al., 1973; Khan et al., 1980/ 81). Our findings suggest that delays in germination caused by the osmotic solutions (Fig. 3 ) must exceed the time when germination ordinarily occurs; i.e., if radicle emergence were to normally begin on the 5th day, the priming treatments must inhibit germination for a longer period to achieve the maximum effects of priming. This feature is illustrated by the lesser effectiveness of priming in water than for longer intervals in salt (Fig. 3). However, priming for longer than 12 days with salts at $300 \mathrm{~mm}$ partially reversed the beneficial effects of priming (Fig. 2), a phenomenon referred to as "overpriming" (Ely and Heydecker, 1981). Although we observed a small increase in $\mathrm{T}_{50}$ (Fig. 2), there was no observable decrease in FGP for priming with $\mathrm{Na}_{2} \mathrm{SO}_{4}$ and $\mathrm{K}_{2} \mathrm{SO}_{4}$. Thus, any problems that arise from the exposure to high ion concentrations for extended periods are minor consequences of salt priming in pepper.

Our findings demonstrate that 1) salt solutions can serve efficiently as priming agents for pepper without reducing the FGP, 2) a specific ion or salt was not essential in priming pepper seeds, and 3) they support previous studies indicating that effective priming is strongly dependent on both the osmotic potential of the priming solution and the duration of the treatment.

\section{Literature Cited}

Atherton, J.G. and A.M. Farooque. 1983. High temperature and germination in spinach. II. Effects of osmotic priming. Scientia Hort. 19:221227.

Bodsworth, S. and J.D. Bewley. 1981. Osmotic priming of crop species with polyethylene glycol as a means of enhancing early and synchronous germination at cool temperatures. Can. J. Bot. 59:672-676.

Bradford, K. 1986. Manipulation of seed water relations via osmotic priming to improve germination under stress conditions. HortScience 21:1105-1112.

Brocklehurst, P.A. and J. Dearman. 1983. Interactions between seed priming treatments and nine seed lots of carrots, celery and onion. I. Laboratory germination. Ann. Applied Biol. 102:577-584.

Brocklehurst, P.A. and J. Dearman. 1984. A comparison of different chemicals for osmotic treatment of vegetable seed. Ann. Applied Biol. 105:391-398

Ely, P.R. and W. Heydecker. 1981. Fast germination of parsley seeds. Scientia Hort. 15:127136.

Haigh, A.H. and E.W.R. Barlow. 1987. Germination and priming of tomato, carrot, onion and sorghum seeds in a range of osmotica. J. Amer. Soc. Hort. Sci. 112:202-208.

Hegarty, T.W. 1977. Seed activation and seed germination under moisture stress. New Phytol. 78:349-359.

Heydecker, W. and P. Coolbear. 1977. Seed treatments to improve performance-survey and attempted prognosis. Seed Sci. Technol. 5:353425.

Heydecker, W. and B.M. Gibbins. 1978. The 'priming' of seeds. Acta Hort. 83:213-215.

Heydecker, W., J. Higgins, and R.L. Gulliver. 1973. Accelerated germination by osmotic seed treatment. Nature 246:42-44.

Khan, A.A., N.H. Peck, and C. Samimy. 1980/ 81. Seed osmoconditioning: Physiological and biochemical changes. Israel J. Bot. 29:133-144.

Levitt, J. and P.C. Harem. 1943. A method of increasing the rate of seed germination of $\mathrm{Ta}$ raacum Kok-saghyz. Plant Physiol. 18:288-293.

Nerson, H. and A. Govers. 1986. Salt priming of muskmelon for low temperature germination. Scientia Hort. 28:85-91.

Orchard, T.J. 1977. Estimating the parameters of plant seedling emergence. Seed Sci. Technol. 5:61-69.

O'Sullivan, J. and W.J. Bouw. 1984. Pepper seed treatment for low temperature germination. Can. J. Plant Sci. 64:387-393.

Sundstrom, F.J. and R.L. Edwards. 1989. Pepper seed respiration, germination, and seedling development following seed priming. HortScience 24:343-345.

Sundstrom, F.J., R.B. Reader, and R.L. Edwards. 1987. Effect of seed treatment and planting method on Tabasco pepper. J. Amer. Soc. Hort. Sci. 112:641-644.

Yaklich, R.W. and M.D. Orzolek. 1977. Effect of polyethylene glycol-6000 on pepper seed. HortScience 12:263-264. 